\title{
Chemical modification of Aspergillus niger $\beta$-glucosidase and its catalytic properties
}

\author{
Samia A. Ahmed ${ }^{1}$, Nefisa M.A. El-Shayeb ${ }^{1}$, Abdel-Gawad M. Hashem², \\ Shireen A.A. Saleh ${ }^{1}$, Ahmed F. Abdel-Fattah ${ }^{1}$ \\ 1Department of Chemistry of Natural and Microbial Products, National Research Centre, Cairo, Egypt. \\ 2Microbiology and Immunology Faculty of Pharmacy, Cairo University, Cairo, Egypt.
}

Submitted: December 24, 2012; Approved: June 6, 2014.

\begin{abstract}
Aspergillus niger $\beta$-glucosidase was modified by covalent coupling to periodate activated polysaccharides (glycosylation). The conjugated enzyme to activated starch showed the highest specific activity ( $128.5 \mathrm{U} / \mathrm{mg}$ protein). Compared to the native enzyme, the conjugated form exhibited: a higher optimal reaction temperature, a lower Ea (activation energy), a higher $\mathrm{K}_{\mathrm{m}}$ (Michaelis constant) and Vmax (maximal reaction rate), and improved thermal stability. The calculated $t_{1 / 2}$ (half-life) values of heat in-activation at $60^{\circ} \mathrm{C}$ and $70^{\circ} \mathrm{C}$ were 245.7 and $54.5 \mathrm{~min}$ respectively, whereas at these temperatures the native enzyme was less stable ( $t_{1 / 2}$ of 200.0 and 49.5 min respectively). The conjugated enzyme retained 32.3 and $29.7 \%$, respectively from its initial activity in presence of $5 \mathrm{mM}$ Sodium Dodecyl Sulphate (SDS) and $p$-Chloro Mercuri Benzoate ( $p$-CMB), while the native enzyme showed a remarkable loss of activity (retained activity 1.61 and $13.7 \%$, respectively). The present work has established the potential of glycosylation to enhance the catalytic properties of $\beta$-glucosidase enzyme, making this enzyme potentially feasible for biotechnological applications.
\end{abstract}

Key words: $\beta$-glucosidases, glycosylation, soluble polysaccharides, enzyme stability.

\section{Introduction}

$\beta$-glucosidases are enzymes that hydrolyze cellulose ( $\beta$-1,4-glucan or $\beta$-D- glucosidic linkages) resulting in the formation of glucose, cellobiose, cellooligosaccharides, and the like (Su et al., 2010; Cai et al., 2012). Efficient hydrolysis of cellulose requires the synergistic activities of three types of enzymes: cellobiohydrolase, endo- $\beta-1,4-$ glucanase, and $\beta$-glucosidase (Chauve et al., 2010; Singh et al., 2011; Cai et al., 2012). $\beta$-glucosidase (EC 3.2.1.21), catalyses the final step of cellulose hydrolysis (i.e., the breakdown of cellobiose to glucose). The supplementation of this enzyme to cellulose preparations, in order to obtain higher rates and extent of saccharification of cellulose, has been recommended (Wood and Wiseman, 1982). Cellulases have a great application prospect in many fields, such as medicine, textile, chemical engineering, paper engineering, food and fermentation industries, commercial detergents, tobacco, waste water treatment, feed additives etc. (Howard et al., 2003; Su et al., 2010). The application of cellulase has very important significance in solving problems related with raw materials in industry and agriculture, the energy crisis, and environmental pollution and so on (Cai et al., 2012). An efficient cellulose hydrolysis requires a stable $\beta$-glucosidase for the utilization of abundant cellulosic waste material on an industrial scale (Rashid and Siddiqui, 1996). There are several major and principally different routes to obtain cellulases with improved stability properties to date: (a) by selecting organisms living in appropriate extreme environments (Huang et al., 2005; Kubartova et al., 2007), (b) by gene recombination and genetic engineering (Liu et al., 2006; Kim et al., 2007), (c) by immobilization (Sinegania et al., 2005; Singh et al., 2011), and (d) by chemical modification (Yang et al., 2009; Cai et al., 2012). Chemical modification is the process of covalent attachment of special groups of modifiers to the side-chain group of certain amino-acid residues in the enzyme. There are few reports about stabilization of $\beta$-glucosidase by co- 
valent coupling to soluble polysaccharides (Rashid and Siddiqui, 1998; Abdel-Naby, 1999).

In the present study, Aspergillus niger $\beta$-glucosidase was covalently immobilized on to water soluble carrier (polysaccharides). The catalytic properties and the stability of modified enzyme have been compared to those of native enzyme.

\section{Materials and Methods}

\section{Microorganism}

Aspergillus niger strain was obtained from the Center of Culture Collection of National Research Center, Cairo, Egypt, and sub-cultured every 3 weeks and stored at $4{ }^{\circ} \mathrm{C}$ in PDA slants.

\section{Enzyme production}

For inoculum preparation, spores from A.niger were produced on PDA slants for 5 days at $30{ }^{\circ} \mathrm{C}$. One $\mathrm{mL}$ of spore suspension $\left(6 \times 10^{10}\right.$ spores $)$ was then inoculated in $250 \mathrm{~mL}$-Erlenmeyer flasks containing $50 \mathrm{~mL}$ production medium. The production medium was prepared from a mixture of $3 \mathrm{~g} \mathrm{NH}_{4} \mathrm{Cl}, 17 \mathrm{~g}$ citric acid, $3 \mathrm{~g} \mathrm{KH}_{2} \mathrm{PO}_{4}, 0.5 \mathrm{~g}$ $\mathrm{MgSO}_{4} .7 \mathrm{H}_{2} \mathrm{O}, 0.5 \mathrm{~g} \mathrm{CaCl}_{2}, 0.2 \mathrm{~mL}$ triton and $10 \mathrm{~mL}$ milk whey, in $1000 \mathrm{~mL}$ wheat bran extract (1\% w/v) with $\mathrm{pH}$ adjusted to 7.0. The flasks were shaken at $150 \mathrm{rpm}$ and $30^{\circ} \mathrm{C}$ for 7 days. The culture was filtered through cloth to remove the mycelia. The crude supernatant was used for enzyme modification.

\section{Oxidation of carbohydrate used for the modification}

Agar, dextran A $\left(200 \times 10^{3}-275 \times 10^{3}\right)$, dextran $70 \times$ $10^{3}$, glucomannan, galactomannan, pectin and soluble starch were used in the present study, all were obtained from Sigma. Activation of polysaccharide was done according to Ben Ammar et al. (2002) with some modification as follows: $1 \mathrm{~g}$ of each polysaccharide was dissolved into $40 \mathrm{~mL}$ of $0.25 \mathrm{M}$ periodate solution and gently shaked at $50 \mathrm{rpm}$ at $37^{\circ} \mathrm{C}$ for $6 \mathrm{~h}$. After that, $1.2 \mathrm{~mL}$ of ethylene glycol were added and allowed to react for $1 \mathrm{~h}$. The reaction mixture was dialyzed against water at $4{ }^{\circ} \mathrm{C}$ for $2 \mathrm{~h}$ then lyophilized.

\section{Covalent coupling of $\beta$-glucosidase to activated polysaccharide}

Forty units of enzyme and $150 \mathrm{mg}$ oxidized polysaccharide were combined in citrate buffer $\mathrm{pH}$ 4.8. The mixture was allowed to stand at $4{ }^{\circ} \mathrm{C}$ overnight. Modified $\beta$-glucosidase was precipitated with $90 \%$ acetone, centrifuged at $4{ }^{\circ} \mathrm{C}$ and $3000 \mathrm{rpm}$ for $15 \mathrm{~min}$, the precipate was dried and used as modified enzyme.

\section{Enzymatic assay}

$\beta$-glucosidase activity was determined according to Abdel-Naby (1999) using 0.4\% (w/v) cellobiose solution in citrate buffer ( $0.05 \mathrm{M}, \mathrm{pH} 4.8)$. The glucose released was determined by glucose oxidase / peroxidase reagent. One unit $(\mathrm{U})$ of enzyme activity was defined as the amount of enzyme required to release $1 \mu \mathrm{mol}$ of glucose per minute under assay conditions.

\section{Protein determination}

Protein contents of enzyme were estimated by method of Lowry et al. (1951).

\section{Thermal stability}

Both native and conjugated $\beta$-glucosidase were held at different temperatures $\left(40-70{ }^{\circ} \mathrm{C}\right)$ for $2 \mathrm{~h}$ before activity assay, with samples being drawn for the assay at $15-\mathrm{min}$ intervals.

\section{pH stability}

The $\mathrm{pH}$ stability was examined by measuring the residual activity of the enzyme after incubation at $0.05 \mathrm{M}$ buffer with different $\mathrm{pHs}$ using citrate buffer ( $\mathrm{pH} 2.5-6.0$ ), citrate phosphate buffer ( $\mathrm{pH}$ 6.5-7.5), and phosphate buffer (pH 7.5-8.0).

\section{Results and Discussion}

The variation of activity obtained for glycosylated $\beta$-glucosidase was affected by the types of modifiers and the molecular weight of carbohydrate residue linked to the enzyme (Figure 1). Among all preparations tested, the enzyme coupled to activated soluble starch showed higher specific activity (128.5 U/ mg protein) than the native enzyme (29.6 U mg/ protein). This result was due to the conjugation to the active protein in crude enzyme preparation. It is clear from the results that the crude enzyme contains a variety of proteins in addition to the $\beta$-glucosidase. Similar result was obtained by Singh et al. (2011) on immobilized $\beta-1,4$-glucosidase onto functionalized silicon oxide nanoparticles.

\section{Properties of native and starch conjugated cellobiase}

\section{Optimum temperature}

The activities of native and conjugated enzymes were assayed at various temperatures $\left(30-75^{\circ} \mathrm{C}\right)$. The native enzyme had an optimum temperature of $40^{\circ} \mathrm{C}$, whereas that of the conjugated enzyme was shifted to $50{ }^{\circ} \mathrm{C}$. The increase of the optimum temperature is probably a consequence of enhanced thermal stability. Similar result was reported for other glycosylated cellobiases (Abdel-Naby, 1999). The temperature data were replotted in the form of Arrhenius plot (Figure 2) which is related to the activation energy (Ea) by the relationship: $\mathrm{Slope}=\mathrm{Ea} / 2.303 \mathrm{R}$, where $\mathrm{R}$ is the gas constant. Activation energy for both native and conjugated enzymes was 4.55 and $3.87 \mathrm{cal} / \mathrm{mol}$, respectively. Rashid and Siddiqui (1996) reported that poly- 


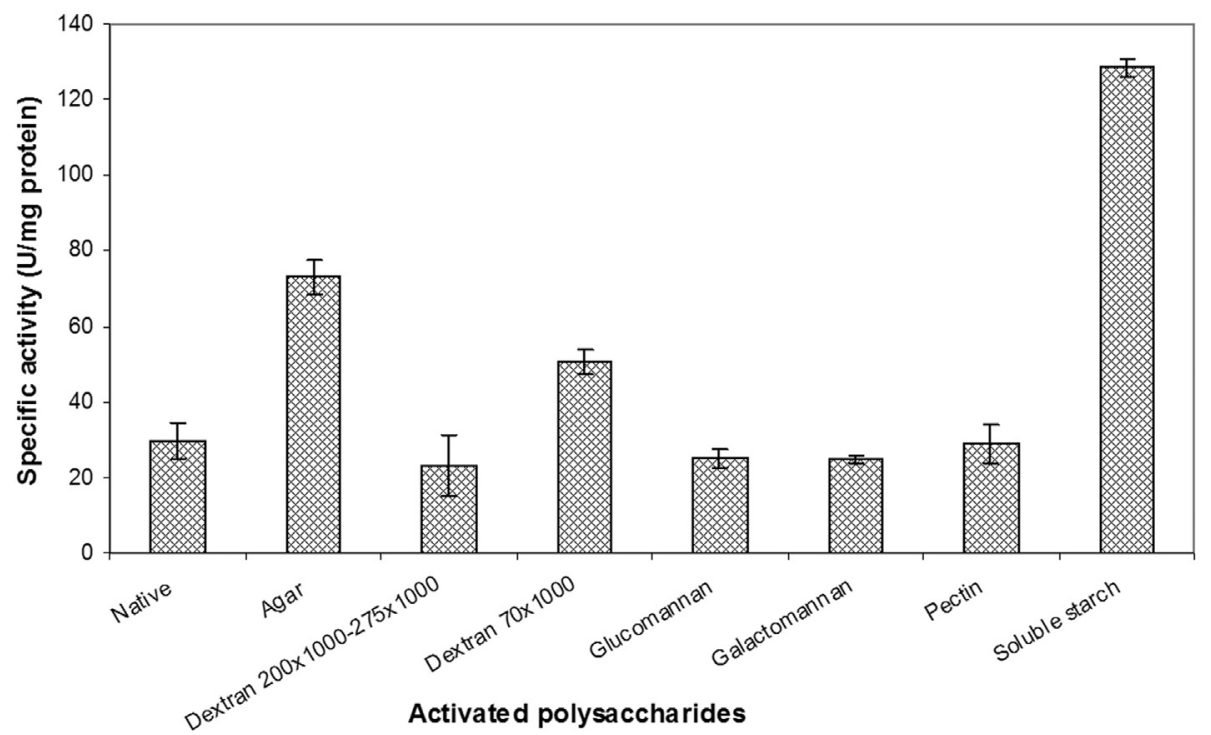

Figure 1 - Covalent coupling of Aspergillus niger $\beta$-glucosidase to periodate activated polysaccharides.

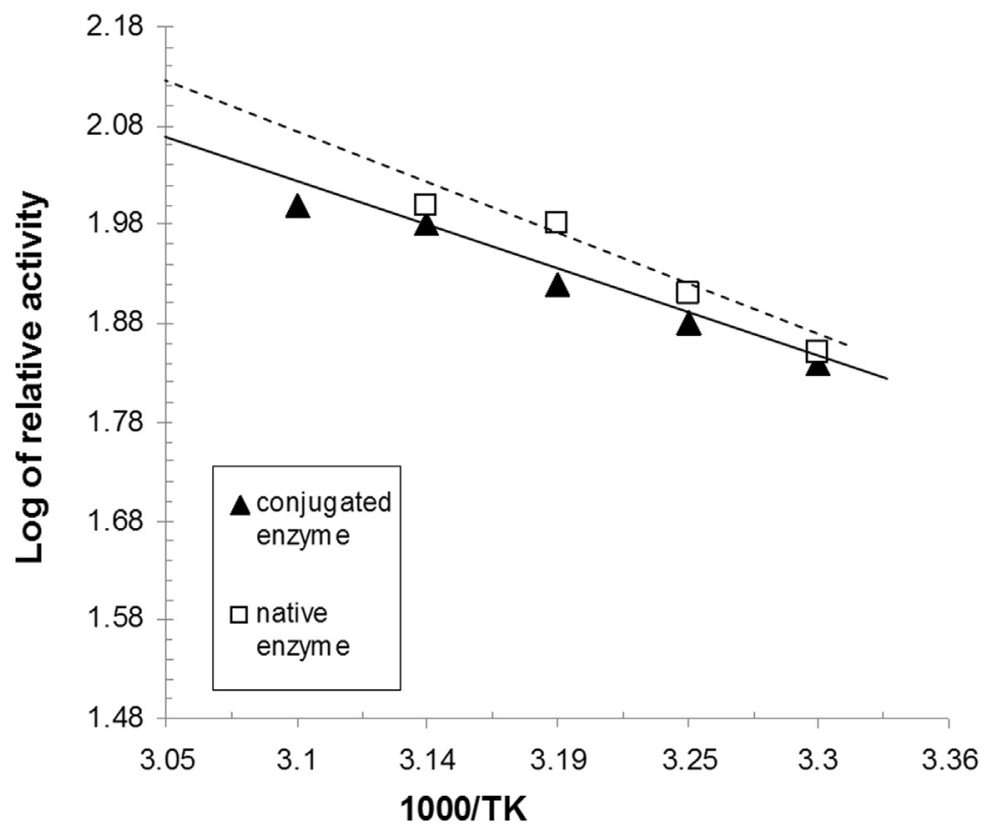

Figure 2 - Arrhenius plots for the native and starch conjugated Aspergillus niger $\beta$ - glucosidase.

saccharide- $\beta$-glucosidase had lower Ea $(55 \mathrm{~kJ} / \mathrm{mol})$ as compared with the native form $(61 \mathrm{~kJ} / \mathrm{mol})$.

\section{Optimum $\mathrm{pH}$}

Optimum $\mathrm{pH}$ of the native and modified $\beta$-glucosidase was studied using $0.05 \mathrm{M}$ of different buffers with different $\mathrm{pH}$ values. Both native and modified enzymes were optimally active at $\mathrm{pH} 4.0$ (Figure 3 ). This means that the ionization of the amino acid residues at the active site remained unaffected by the glycosylation process. AbdelNaby (1999) found that there was no change of the $\mathrm{pH}$ opti- mum for the activity of the native and glycosylated cellobiase.

\section{Thermal stability}

The rates of heat inactivation of the native and conjugated $\beta$-glucosidase were presented in Figure 4A. Covalent coupling of $\beta$-glucosidase to activated starch appeared to enhance its thermal stability as shown total activity of the conjugated enzyme which was retained after $2 \mathrm{~h}$ of heating at $55^{\circ} \mathrm{C}$, while the native enzyme lost about $11 \%$ of its initial activity. This is probably because the formation of mul- 


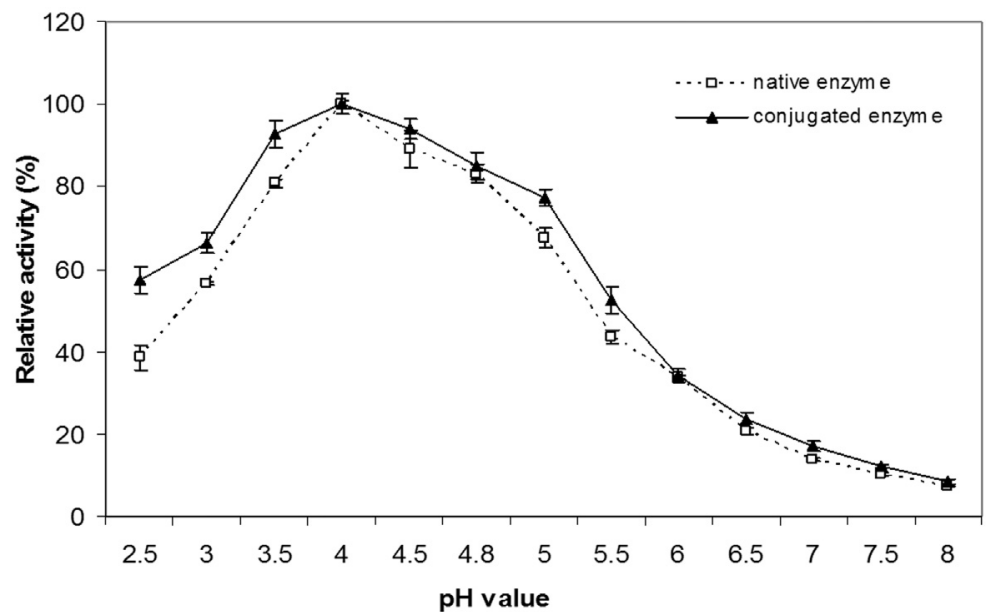

Figure 3 - Optimum $\mathrm{pH}$ of native and starch conjugated Aspergillus niger $\beta$-glucosidase.
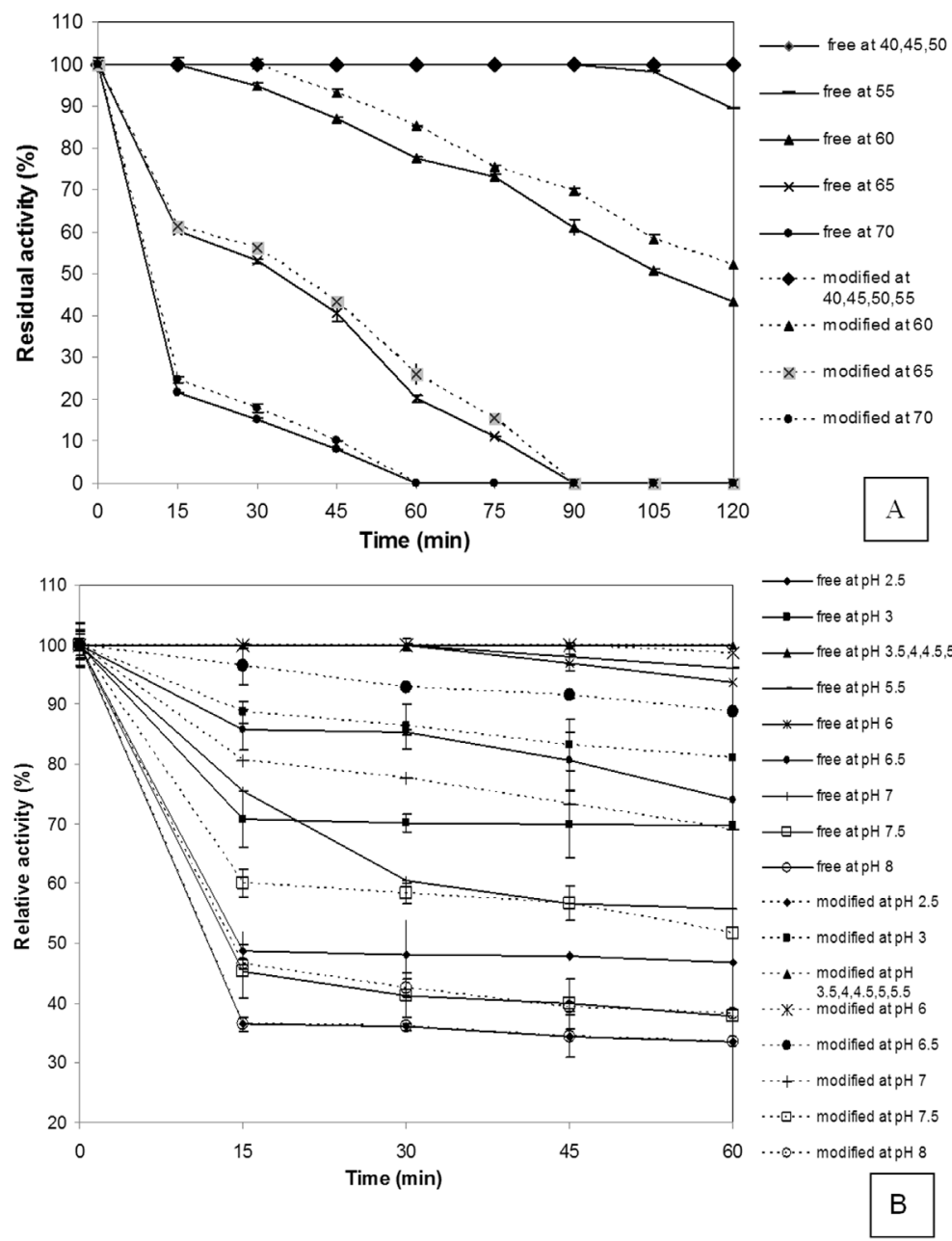

Figure 4 - Thermal stability (A) and pH stability (B) of native and starch conjugated Aspergillus niger $\beta$-glucosidase.

tiple covalent bonds between the $\beta$-glucosidase and polysaccharide reduces conformational flexibility and thermal vibrations, thus preventing the conjugated protein from unfolding and denaturing (Wong et al., 2009; Singh et al.,
2011). Wongkhalaung et al. (1985) reported that cellulase conjugated to soluble polymer retained all initial activity after heating at $60^{\circ} \mathrm{C}$ for $20 \mathrm{~min}$, while the native cellulase lost about $18 \%$ of its activity at the same condition. For ex- 
ample, the calculated half-life $\left(\mathrm{t}_{1 / 2}\right)$ value shows that the heat inactivation of conjugated enzyme at $65{ }^{\circ} \mathrm{C}$ was $67.2 \mathrm{~min}$ whereas at the same temperature the native was less stable ( $\left.\mathrm{t}_{1 / 2} 55.3 \mathrm{~min}\right)$. Glycosylation of $\beta$-glucosidase protected the enzyme against heat in-activation as its halflife for thermal deactivation was increased. Conjugation to polysaccharide induced stability of modified proteins by rigidification of the conformation, which could retain its denaturation (Bund and Singhal, 2002). On the other hand, Srivastava (1991) argued that the hydration effect of the attached carbohydrate may be responsible for improving the stability of conjugated enzymes. Hydrogen binding between the polysaccharide and protein surface as well as intra molecular cross links between protein and polysaccharide has been suggested as causes of thermal stabilization (Zhang et al., 2009).

pH stability

The stability of the conjugated $\beta$-glucosidase at various $\mathrm{pH}$ values was higher than that of the native enzyme (Figure 4B). At pH 3.0 and 8.0 after 30 min the residual activity of the conjugated enzyme was 86.4 and $44.3 \%$ which was higher than that of the native enzyme ( 70.1 and $36.0 \%$, respectively). In general, the glycosylated enzyme was more resistant to acid or alkaline $\mathrm{pH}$ values. In contrast, Abdel-Naby (1999) reported that no change of $\mathrm{pH}$ stability of cellobiase after glycosylation process.

\section{Kinetics of native and conjugated cellobiase}

According to the Michaelis-Menton kinetics, the $\mathrm{v}_{\max }$ (maximum reaction rate) and $\mathrm{k}_{\mathrm{m}}$ (Michaelis constant) of enzymes are determined at optimum assay conditions. Lineweaver-Burk plots of the native and conjugated $\beta$-glucosidase (Figure not shown) gave $\mathrm{k}_{\mathrm{m}}$ of $40 \mathrm{mM}$ and $46.5 \mathrm{mM}$, respectively. With cellobiose, the $\mathrm{v}_{\max }$ of the native and conjugated enzyme were 416.7 and $1111.0 \mathrm{U} / \mathrm{mg}$ protein, respectively. Increasing the $\mathrm{k}_{\mathrm{m}}$ value after glycosylation is most likely a consequence of conformational changes in the enzyme introduced by the glycosylation procedure which renders its active site less accessible to the substrate. In contrast Zhang et al. (2009) reported that $\mathrm{k}_{\mathrm{m}}$ of modified cellulase is smaller than that of natural cellulase. It illustrates that the affinity of the modified form for the substrate is larger than that of the natural form. The specific activity of conjugated $\beta$-glucosidase is higher than that of the native enzyme, consequently, $\mathrm{v}_{\max }$ of modified enzyme is higher than that of native enzyme. Rashid and Siddiqui (1998) found that no significant difference could be detected in the specificity constant $\left(\mathrm{k}_{\mathrm{m}}\right.$ and $\left.\mathrm{v}_{\max }\right)$ between free and glycosylated $\beta$-glucosidase.

\section{Effect of various metal ions}

In this experiment, both the native and conjugated $\beta$-glucosidase were incubated with the tested metal $(5 \mathrm{mM})$ at $30^{\circ} \mathrm{C}$ for $60 \mathrm{~min}$ before mixing with the substrate. The results listed in (Figure 5) indicated that the inhibitory effect of the investigated metal ions was less pronounced with the conjugated enzyme as compared to the native enzyme. This may be due to the protection of the enzyme by immobilization. In presence of Sodium Dodecyl Sulphate (SDS) the conjugated $\beta$-glucosidase retained 32.3\% from its initial activity, while the native enzyme showed a remarkable loss of activity (retained activity 1.61\%). The native enzyme lost 13.8 and $34.4 \%$ of its initial activity in presence of $\mathrm{ZnCl}_{2}$ and Iodo Aceto Amide (IAA). However, under the same conditions, the conjugated $\beta$-glucosidase was more stable with retained activity of 113.3 and $80.3 \%$, respectively. The higher recovered activity of the conjugated form after treatment with chemicals compared to the native enzyme could be attributed to the hydrophilic nature of the polysaccharide attached to it (Srivastava, 1991). Perutz (1978) reported that protein hydration may have a positive effect on stability.

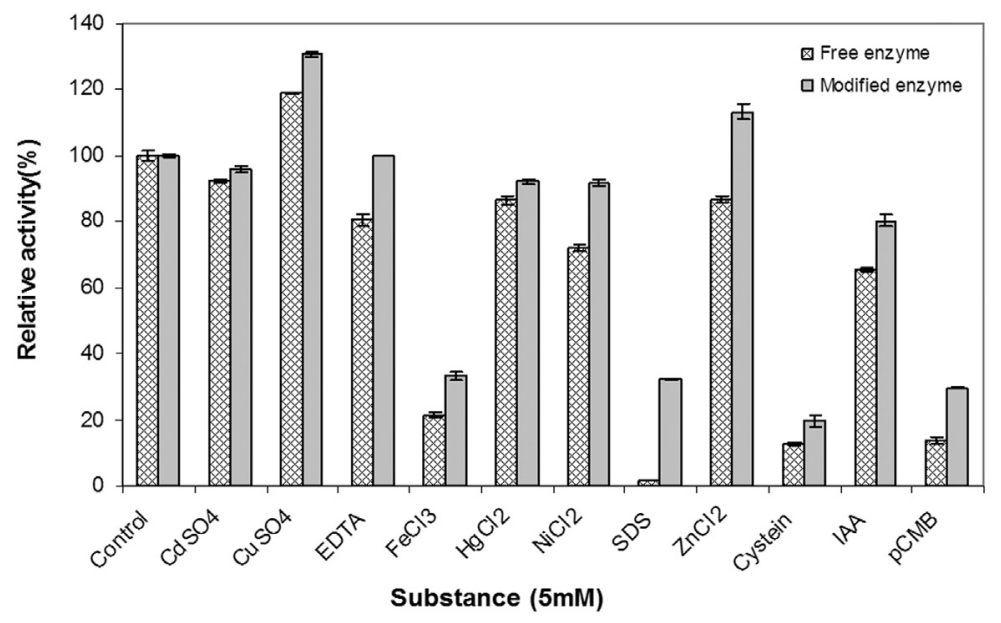

Figure 5 - Effect of metal salts and inhibitors on the activity of native and starch conjugated Aspergillus niger $\beta$-glucosidase. EDTA (Ethylene Diamine Tetra Acetic Acid), SDS (Sodium Dodecyl Sulphate), IAA (Indo Aceto Amide), $p$-CMB ( $p$-Chloro Mercuri Benzoate). 


\section{Conclusion}

There are few reports about modification of the $\beta$-glucosidase enzyme by conjugation to soluble polysaccharides (glycosylation). To our knowledge, this study produced stabilized (modified) $\beta$-glucosidase by covalent coupling to activated polysaccharides. Starch is safe, cheap, readily available on the markets and suitable for industrial application. The glycosylation process improved Aspergillus niger $\beta$-glucosidase stabilities toward temperature, $\mathrm{pH}$, inhibitors which make it more suitable for industrial applications.

\section{References}

Abdel-Naby MA (1999) Stabilization of cellobiase by covalent coupling to soluble polysaccharide. Microbiol Res 154:213-218.

Ben Ammar Y, Motsubara T, Ito K et al. (2002) Some properties of levansucrase of Bacillus natto stabilized with periodate oxidized yeast glucomannan. Enz Microb Technol 30:875882.

Bund RK, Singhal RS (2002) Chemical modification of cellulase by malei anhydride an N-bromosuccinimide for improved detergent stability. J Surfact Deterg 5:1-4.

Cai F, Xie Y, He X et al. (2012) Chemical modification of $\beta$-endoglucanase from Trichoderma viridin by methanol and determination of its catalytic functional groups. Afr J Biotechnol 11:8264-8274.

Chauve M, Mathis H, Hue D et al. (2010) Comparative kinetic analysis of two fungal beta-glucosidases. Biotechnol Biofuels 3:3-8.

Howard RL, Abotsi E, Jansen VRE et al. (2003) Lignocellulose biotechnology: issues of bioconversion and enzyme production. Afr J Biotechnol 2:602-619.

Huang Y, Krauss G, Cottaz S et al. (2005) A highly acid stable and thermostable endo-beta-glucanase from the thermo acidophilic archaeon Sulfolobus solfataricus. Biochem J 385:581-588.

Kim SJ, Lee CM, Kim MY et al. (2007) Screening and characterization of an enzyme with beta-glucosidase activity from environmental DNA. J Microbiol Biotechnol 17:905-912.

Kubartova A, Moukoumi J, Beguiristain T et al. (2007) Microbial diversity during cellulose decomposition in different forest stands: I microbial communities and environmental conditions. Microb Ecol 54:393-405.

Lendewrs JP, Crichton RR (1984) Thermal stabilization of amylolytic enzymes by covalent coupling to soluble polysaccharides. Biotechnol Bioeng 26:1343-1351.
Liu G, Tang X, Tian SL et al. (2006) Improvement of the cellulolytic activity of Trichoderma reesei endoglucanase IV with an additional catalytic domain. World J Microbiol 22:1301-1305.

Lowry OH, Rosenbrough NJ, Farr AL et al. (1951) Protein measurement with the folin phenol reagent. J Biol Chem 193:265-275.

Perutz MF (1978) Electrostatic effects in proteins. Sci 201:11871191.

Rashid MH, Siddiqui KS (1996) The stability of extracellular beta-glucosidase from Aspergillus niger is significantly enhanced by non-covalently attached polysaccharides. Folia Microbiol 41:341-346.

Rashid MH, Siddiqui KS (1998) Thermodynamic and kinetic study of stability of the native and chemically modified $\beta$-glucosidases from Aspergillus niger. Proc Biochem 33:109-115.

Sinegania AS, Emtiazi G, Shariatmadae IH (2005) Sorption and immobilization of cellulase on silicate clay minerals. J Colloid Inter Sci 290:39-44.

Singh RK, Zhang YEW, Nguyen NPT et al. (2011) Covalent immobilization of $\beta$-1,4-glucosidase from Agaricus arvensis onto functionalized silicon oxide nanoparticles. Appl Microbiol Biotechnol 89:337-344.

Srivastava RAK (1991) Studies on stabilization of amylase by covalent coupling to soluble polysaccharides. Enz Microb Technol 13:164-170.

Su ZL, Zhang W, Yu ST (2010) Research progress of cellulase activity. J Anhui Agric Sci 38:10490-10491.

Wong LS, Khan F, Micklefield J (2009) Selective covalent protein immobilization: strategies and applications. Chem Rev 109:4025-4053.

Wongkhalaung C, Kashiwagi Y, Magae Y et al. (1985) Cellulase immobilization on a soluble polymer. Appl Microbiol Biotechnol 21:37-41.

Wood J, Wiseman A (1982) Fungal and other $\beta$-D-glucosidasestheir properties and application. Enz Microb Technol 4:7379.

Yang G, Chen HZ, Liu Y (2009) Effect of additives on thermostability of Trichoderma viride JQF-04 cellulase. Chin. J Appl Environ Biol 15:134-138.

Zhang Y, Tang L, An X et al. (2009) Modification of cellulase and its application to extraction of diosgenin from Dioscorea zingiberensis C.H.Wright. Biochem Engin J 47:80-86.

\section{Associate Editor: Rodrigo da Silva Costa}

All the content of the journal, except where otherwise noted, is licensed under a Creative Commons License CC BY-NC. 